\title{
Factors Related to Stunting In Toddlers Aged 25-59 Months In Posyandu Bontonyeleng Health Center Area
}

\author{
Andi Nurlaily ${ }^{1}$, Andi Tenri Fajriani² ${ }^{2}$ Ely Kurniati ${ }^{3}$, Sri Eka Juniarli ${ }^{4}$ \\ ${ }^{1,2,3,4}$ Departement of Midwife, Stikes Panrita Husada Bulukumba, Indonesia \\ Corresponding Author : Andi Nurlaily \\ Email : andinurlaily@gmail.com
}

\begin{abstract}
ABSTRAC
Stunting is still a problem in nutrition and child development problems in Indonesia. Stunting in South Sulawesi in 2019 amounted to 11.4\%. The highest stunting prevelence is in Bulukumba Regency, which is as much as $7.7 \%$ of short toddlers and $23.3 \%$ of very short toddlers. It is known the factors associated with the occurrence of stunting. The study was observational with case control design using secondary data from the mother's KIA book and primary data through interviews. Variables studied included the mother's height, the mother's education level, economic status, exclusive breastfeeding, birth weight, and gender. Sampling technique using simple rundom sampling. The number of samples in the study was 152 samples which included 76 case groups and 76 control groups. The results of the study obtained variables related to stunting events are maternal height $p$-value 0.015 (95\% CI 1,49540,012), exclusive breastfeeding p-value 0.006 (95\% CI 1,366 - 6,228), sex p-value 0.002 (95\% CI $1,590-7,312)$. The results of the multivariate analysis of maternal height had the highest risk of stunting incidence $(\mathrm{p}=0.015 \mathrm{OR}=7,735,95 \% \mathrm{CI}=1,495-40,012)$ and gender was the most significant factor in stunting p-value events of 0.002 (95\% CI 1,590-7,312). Maternal height is the most dominant factor in relation to stunting events.
\end{abstract}

Keywords: Stunting Incident, Mother's Height, Toddler 


\section{PENDAHULUAN}

Stunting pada anak-anak merupakan salah satu masalah yang cukup serius, karena dikaitkan dengan risiko angka kesakitan dan kematian yang lebih besar, obesitas, dan penyakit tidak menular di masa depan, orang dewasa yang pendek, buruknya perkembangan kognitif, dan rendahnya produktivitas serta pendapatan. Setiap tahun sekitar 10,5 juta kematian anak yang terkait dengan masalah kekurangan gizi. Dimana 98\% dari kematian ini dilaporkan terjadi di negara-negara berkembang, UNICEF 2007.

Faktor-faktor yang menyebabkan terjadinya stunting sangat banyak diantaranya yaitu BBLR. Bayi yang berat lahirnya kurang dari 2.500 gram akan membawa risiko kematian, gangguan pertumbuhan anak, termasuk dapat berisiko menjadi pendek jika tidak ditangani dengan baik. Hal ini juga didukung oleh penelitian yang dilakukan oleh Tiwari yang menyatakan bahwa anak dengan riwayat kelahiran BBLR berisiko menderita stunting dibandingkan dengan anak yang tidak menderita BBLR. ${ }^{11}$ Penelitian yang dilakukan di Nigeria juga menyebutkan bahwa anak yang mengalami BBLR berisiko menderita stunting, Akombi, dkk 2017. Stunting merupakan salah satu masalah yang menghambat perkembangan manusia secara global. Pada saat ini terdapat sekitar 162 juta anak berusia dibawah lima tahun mengalami stunting. Jika tren seperti ini terus berlanjut diproyeksikan bahwa pada tahun 2025 terdapat 127 juta anak berusia dibawah lima tahun akan mengalami stunting, WHO, 2013. Menurut United Nations Children's Emergency Fund (UNICEF) lebih dari setengah anak stunting atau sebesar 56\% tinggal di ASIA dan lebih dari sepertiga atau sebesar 37\% tinggal di Afrika, UNICEF 2016.

Indonesia masih mengalami permasalahan dalam masalah gizi dan tumbuh kembang anak. UNICEF mengemukakan sekitar $80 \%$ anak stunting terdapat di 24 negara berkembang di Asia dan Afrika. ${ }^{3}$ Indonesia merupakan negara urutan kelima yang memiliki prevalensi anak stunting tertinggi setelah India, China, Nigeria dan Pakistan. Saat ini, prevalensi anak stunting di bawah 5 tahun di Asia Selatan sekitar 38\%. ${ }^{4}$ Berdasarkan kajian riset diketahui faktor yang menyebabkan terjadinya stunting. Faktor penyebab stunting dari ibu yaitu, tingkat pendidikan ibu, dan tinggi badan ibu. Faktor penyebab stunting dari bayi yaitu riwayat BBLR, jenis kelamin anak, dan riwayat pemberian ASI ekslusif. Faktor penyebab stunting dari faktor sosial yaitu status ekonomi.

Dengan diketahuinya fakta-fakta tersebut maka akan diteliti lebih lanjut tentang faktor- faktor yang berhubungan dengan stunting pada balita usia 25-59 bulan di Posyandu Wilayah Puskesmas Bontonyeleng.

\section{METODE PENELITIAN}

\section{Lokasi dan Rancangan penelitian}

Penelitian dilakukan di Posyandu Wilayah Puskesmas Bontonyeleng. Dipilihnya Puskesmas Bontonyeleng karena Puskesmas Bontonyeleng merupakan salah satu Puskesmas penyumbang angka stunting di Bulukumba, yaitu sebanyak 549 anak yang menderitta 
stunting. Waktu penelitian dilaksanakan pada bulan November- Desember 2017. Penelitian ini merupakan penelitian observasional dengan desain penelitian case control. Pada studi kasus kontrol observasi atau pengukuran variabel bebas dan variabel tergantung tidak dilakukan pada saat yang sama. Penelitian dimulai dengan melakukan pengukuran variabel tergantung, yakni efek, sedangkan variabel bebasnya dicari secara retrospektif; karena itu studi case control disebut dengan studi longitudinal, artinya subyek tidak hanya diobservasi pada satu saat tetapi diikuti selama periode yang di tentukan. Sastroasmoro, 2014.

\section{Populasi dan sampel}

Populasi adalah wilayah generalisasi yang terdiri atas, obyek/subjek yang mempunyai kuantitas dan karakteristik tertentu yang ditetapkan oleh peneliti untuk dipelajari dan kemudian ditarik kesimpulannya, Notoatmodjo, S. 2012. Populasi target penelitian ini adalah balita usia 25- 59 bulan di Posyandu Wilayah Puskesmas Bontonyeleng.

Sampel dalam penelitian ini adalah balita usia 25-59 bulan yang tidak mengalami stunting sebagaicontrol dan balita usia 25-59 bulan dan yang mengalami stunting sebagai kelompok kasus.Teknik pengambilan sampel yaitu dengan simple random sampling. Pengambilan sampel didasarkan pada prinsip bahwa setiap subyek dalam populasi (terjangkau) mempunyai kesempatan yang sama untuk terpilih atau untuk tidak terpilih sebagai sampel penelitian.

\section{Metode pengumpulan data}

Jenis data dalam penelitian ini adalah data sekunder dan primer. Instrumen yang digunakan untuk mendapatkan data primer dalam penelitian ini adalah kuesioner (Angket). Angket adalah teknik pengumpulan data yang dilakukan dengan cara memberi seperangkat pertanyaan baru atau pernyataan tertulis kepada responden untuk dijawab, Sugiyono. 2010.

Data sekunder diperoleh dari buku KIA ibu yang beradadi Wilayah Kerja Puskesmas Bontonyeleng. Data yang dibutuhkan ditulis dengan panduan daftar isian dan master tabel yang dibuat peneliti. Daftar isian digunakan untuk memastikan semua data yang dibutuhkan untuk penelitian tercatat dari masing-masing buku KIA ibu. Sedangkan untuk data primer diperoleh dari kuesioner yang diberikan pada ibu.

\section{Analisis data}

Pada penelitian ini dilakukan analisis untuk mengetahui hubungan tinggi badan, usia kehamilan, tingkat pendidikan, status ekonomi, pemberian ASI, berat bayi lahir, dan jenis kelamin dengan kejadian stunting pada balita usia 25-59 bulan. Pada penelitian ini menggunakan uji statistik Chisquare dengan uji uji alternatifnya yaitu uji Fisher's Exact Test. Odds Ratio digunakan sebagai indikator adanya hubungan sebab akibat antara faktor risiko dan efek. Interpretasi OR lebih dari 1 menunjukkan bahwa faktor yang diteliti memang merupakan faktor risiko, bila $\mathrm{OR}=1$ atau mencakup 
angka 1 berarti bukan merupakan faktor, dan bila kurang dari 1 berarti merupakan faktor protektif.

Analisa multivariat dilakukan untuk mengetahui hubungan lebih dari satu variabel independent dengan satu variabel dependent yaitu menganalisa pengaruh variabel independent (tinggi badanm, tingkat pendidikan, status ekonomi, pemberian asi, berat lahir, jenis keamin) terhadap variabel dependent (kejadian stunting) dengan menggunakan analisis regresi logistik (logistic regression), untuk mengetahui variabel independent yang mana yang lebih erat hubungannya dengan variabel dependent dengan nilai $\mathrm{p}<0,25$. Notoatmodjo, S. 2012.

\section{HASIL}

Pada tabel 1. memperlihatkan bahwa karakteristik responden kelompok balita stunting dari ibu dengan tinggi badan kurang yaitu sebesar 18,4\%, sedangkan balita yang tidak stunting dengan tinggi badan ibu kurang hanya sebesar 2,6\%. Pada tingkat pendidikan, balita stunting dengan tingkat pendidikan ibu yang rendah yaitu sebesar $61,8 \%$, sedangkan balita yang tidak mengalami stunting dengan tingkat pendidikan ibu yang rendah sebesar 36,8\%.

Kelompok kasus dengan status ekonomi keluarga yang rendah yaitu sebesar 76,3\%, sedangkan kelompok kontrol dengan status ekonomi rendah sebesar 55,3\%. Pada pemberian ASI Eksklusif, balita yang tidak diberikan ASI Eksklusif dan mengalami stunting yaitu sebesar 67,1\%, sedangkan balita yang tidak diberi ASI Eksklusif dan tidak mengalami stunting yaitu sebesar 38,2\%. Pada berat lahir bayi, balita yang lahir dengan berat lahir kurang dan mengalami stunting yaitu sebesar $21,1 \%$, sedangkan balita yang tidak mengalami stunting dengan berat lahir kurang yaitu sebesar 6,6\%. Faktor terakhir jenis kelamin, balita dengan jenis kelamin laki-laki yang mengalami stunting yaitu sebesar 63,2\%, sedangkan balita dengan jenis kelamin laki-laki yang tidak mengalami stunting yaitu sebesar 35,5\%.

Tabel 1. Distribusi Frekuensi Subjek Berdasarkan Analisa Variabel Independen terhadap Kejadian Stunting di Wilayah Kerja Puskesmas Bontonyeleng

\begin{tabular}{|c|c|c|c|c|c|c|}
\hline \multirow{3}{*}{ Variabel Independen } & \multicolumn{4}{|c|}{ Kejadian Stunting } & \multicolumn{2}{|c|}{ Jumlah } \\
\hline & \multicolumn{2}{|c|}{ Ya } & \multicolumn{2}{|c|}{ Tidak } & \multirow[b]{2}{*}{$\mathbf{N}$} & \multirow[b]{2}{*}{$\%$} \\
\hline & $\mathbf{N}$ & $\%$ & $\mathbf{N}$ & $\%$ & & \\
\hline \multicolumn{7}{|l|}{ Tinggi Badan Ibu } \\
\hline - $\quad$ Berisiko $(\leq 145 \mathrm{~cm})$ & 14 & $18,4 \%$ & 2 & $2,6 \%$ & 16 & $10,5 \%$ \\
\hline Tidak Berisiko (> 145cm) & 62 & $81,6 \%$ & 74 & $97,4 \%$ & 136 & $89,5 \%$ \\
\hline \multicolumn{7}{|l|}{ Tingkat Pendidikan } \\
\hline $\begin{array}{l}\text { - Rendah(tidak sekolah, SD } \\
\text { SMP) }\end{array}$ & 47 & $61,8 \%$ & 28 & $36,8 \%$ & 75 & $49,3 \%$ \\
\hline $\begin{array}{c}\text { Tinggi (SMA, Perguruan } \\
\text { Tinggi) }\end{array}$ & 29 & $38,2 \%$ & 48 & $63,2 \%$ & 77 & $50,7 \%$ \\
\hline
\end{tabular}




\begin{tabular}{|c|c|c|c|c|c|c|}
\hline \multicolumn{7}{|l|}{ Status Ekonomi } \\
\hline - $\quad$ Rendah(<Rp.1.337.650,00) & 58 & $76,3 \%$ & 42 & $55,3 \%$ & 100 & $65,8 \%$ \\
\hline Tinggi (>Rp.1.337.650,00) & 18 & $23,7 \%$ & 34 & $44,7 \%$ & 52 & $34,2 \%$ \\
\hline \multicolumn{7}{|l|}{ Pemberian ASI } \\
\hline - Tidak Eksklusif & 51 & $67,1 \%$ & 29 & $38,2 \%$ & 80 & $52,6 \%$ \\
\hline - Eksklusif & 25 & $32,9 \%$ & 47 & $61,8 \%$ & 72 & $47,4 \%$ \\
\hline \multicolumn{7}{|l|}{ Berat Lahir } \\
\hline - $\quad$ Kurang (> 2.500gram) & 16 & $21,1 \%$ & 5 & $6,6 \%$ & 21 & $13,8 \%$ \\
\hline - $\quad$ Cukup $(<2.500$ gram $)$ & 60 & $78,9 \%$ & 71 & $93,4 \%$ & 131 & $86,2 \%$ \\
\hline \multicolumn{7}{|l|}{ Jenis Kelamin } \\
\hline - Laki-laki & 48 & $63,2 \%$ & 27 & $35,5 \%$ & 75 & $49,3 \%$ \\
\hline - Perempuan & 28 & $36,8 \%$ & 49 & $64,5 \%$ & 77 & $50,7 \%$ \\
\hline
\end{tabular}

Hasil analisis pada tabel 2. hubungan antara tinggi badan ibu dan kejadian stunting didapatkan bahwa balita stunting dan memiliki ibu dengan tinggi badan berisiko yaitu sebesar 18,4\%. Balita yang tidak stunting dan memiliki ibu dengan tinggi badan berisiko yaitu sebesar 2,6\%. Hasil uji statistik didapatkan p-value 0,004 berarti dapat disimpulkan bahwa ada hubungan antara tinggi badan ibu dengan Kejadian Stunting. Stunting berpeluang 8,355 kali $(95 \%$ CI 1,828-38,182) pada balita yang lahir dari ibu dengan tinggi badan kurang dari $145 \mathrm{~cm}$ dibanding balita yang lahir dari ibu dengan tinggi lebih dari $145 \mathrm{~cm}$.

Hasil analisis hubungan antara tingkat pendidikan ibu dan kejadian stunting didapatkan bahwa balita yang mengalami stunting dan memiliki ibu dengan tingkat pendidikan rendah yaitu sebesar $61,8 \%$. Balita yang tidak mengalami stunting dan memiliki ibu dengan tingkat pendidikan rendah yaitu sebesar $36,8 \%$. Hasil uji statistik didapatkan p- value 0,003 berarti dapat disimpulkan bahwa ada hubungan antara tingkat pendidikan ibu dengan kejadian stunting. Stunting berpeluang 2,778 kali (95\% CI 1,441-5,358) pada balita yang lahir dari ibu dengan tingkat pendidikan rendah dibanding balita yang lahir dari ibu dengan tingkat pendidikan tinggi.

Hasil analisis hubungan antara status ekonomi dan kejadian stunting didapatkan bahwa balita yang mengalami stunting dan memiliki status ekonomi rendah yaitu sebesar 76,3\%, sedangkan balita yang tidak mengalami stunting dan memiliki status ekonomi rendah yaitu sebesar 55,3\%. Hasil uji statistik didapatkan p-value 0,010 berarti dapat disimpulkan bahwa ada hubungan antara status ekonomi dengan kejadian stunting. Stunting berpeluang 2,608 kali (95\% CI 1,301-5,231) pada balita yang memiliki status ekonomi rendah dibanding balita dengan status ekonomi tinggi.

Hasil analisis hubungan antara pemberian ASI eksklusif dan kejadian stunting didapatkan bahwa balita yang mengalami stunting dan tidak ASI eksklusif yaitu sebesar 67,1\%, 
sedangkan balita yang mengalami stunting dan tidak mendapat ASI eksklusif yaitu sebesar $38,2 \%$. Hasil uji statistik didapatkan p-value 0,001 berarti dapat disimpulkan bahwa ada hubungan antara pemberian ASI eksklusif dengan kejadian stunting. Stunting berpeluang 3,306 kali (95\% CI 1,699-6,433) pada balita yang tidak mendapatkan ASI eksklusif dibanding balita yang mendapat ASI eksklusif.

Hasil analisis hubungan antara pemberian berat lahir dan kejadian stunting didapatkan bahwa balita yang mengalami stunting dan lahir dengan berat lahir kurang yaitu sebesar 21,1\%. Balita yang tidak mengalami stunting juga lahir dengan berat lahir kurang yaitu sebesar 6,6\%. Hasil uji statistik didapatkan p-value 0,019 berarti dapat disimpulkan bahwa ada hubungan antara berat lahir dengan kejadian stunting. Stunting berpeluang 3,787 kali (95\% CI 1,310-10,945) pada balita yang lahir berat lahir kurang dibanding balita yang lahir dengan berat lahir cukup.

Hasil analisis hubungan antara jenis kelamin dan kejadian stunting didapatkan bahwa balita yang mengalami stunting dan berjenis kelamin laki-laki yaitu sebesar 63,2\%. Balita yang tidak mengalami stunting dan berjenis kelamin laki-laki yaitu sebesar 35,5\%. Hasil uji statistik didapatkan p-value 0,001 berarti dapat disimpulkan bahwa ada hubungan antara jenis kelamin dengan kejadian stunting. Stunting berpeluang 3,111 kali (95\% CI 1,605-6,030) pada balita yang berjenis kelamin laki-laki dibanding balita yang berjenis kelamin perempuan.

Tabel 2. Hasil Analisis Bivariat Variabel Independen terhadap Kejadian Stunting di Wilayah Kerja Puskesmas Bontonyeleng

\begin{tabular}{|c|c|c|c|c|c|c|c|}
\hline \multirow{3}{*}{ Variabel } & \multicolumn{4}{|c|}{ Kejadian Stunting } & \multirow[t]{3}{*}{ P Value } & \multirow[t]{3}{*}{ OR } & \multirow[t]{3}{*}{ CI } \\
\hline & \multicolumn{2}{|c|}{ Ya } & \multicolumn{2}{|c|}{ Tidak } & & & \\
\hline & $\mathbf{N}$ & $\%$ & $\mathbf{N}$ & $\%$ & & & \\
\hline Tinggi Badan Ibu & & & & & & & \\
\hline Berisiko $(\leq 145 \mathrm{~cm})$ & 14 & $18,4 \%$ & 2 & $2,6 \%$ & & & \\
\hline Tidak Berisiko (> 145cm) & 62 & $81,6 \%$ & 74 & $97,4 \%$ & 0,004 & 8,355 & $1,828-38,182$ \\
\hline \multicolumn{8}{|l|}{ Tingkat Pendidikan } \\
\hline $\begin{array}{c}\text { Rendah(tidak sekolah, } \\
\text { SD,SMP) }\end{array}$ & 47 & $61,8 \%$ & 28 & $36,8 \%$ & & & \\
\hline $\begin{array}{l}\text { Tinggi (SMA - Perguruan } \\
\text { Tinggi) }\end{array}$ & 29 & $38,2 \%$ & 48 & $63,2 \%$ & 0,003 & 2,778 & $1,441-5,358$ \\
\hline \multicolumn{8}{|l|}{ Status Ekonomi } \\
\hline Rendah $(<$ Rp.1.337.650,00) & 58 & $76,3 \%$ & 42 & $55,3 \%$ & 0,010 & 2,608 & $1,301-5,231$ \\
\hline Tinggi (> Rp.1.337.650,00) & 18 & $23,7 \%$ & 34 & $44,7 \%$ & & & \\
\hline \multicolumn{8}{|l|}{ Pemberian ASI } \\
\hline Tidak Eksklusif & 51 & $67,1 \%$ & 29 & $38,2 \%$ & 0,001 & 3,306 & $1,699-6,433$ \\
\hline Eksklusif & 25 & $32,9 \%$ & 47 & $61,8 \%$ & & & \\
\hline Berat Lahir & & & & & & & \\
\hline
\end{tabular}




\begin{tabular}{l|ccccccc}
\hline Kurang(> 2.500gram & 16 & $21,1 \%$ & 5 & $6,6 \%$ & 0,019 & 3,787 & $1,310-10,945$ \\
Cukup(<2.500gram) & 60 & $78,9 \%$ & 71 & $93,4 \%$ & & & \\
\hline Jenis Kelamin & & & & & & & \\
Laki-laki & 48 & $63,2 \%$ & 27 & $35,5 \%$ & 0,001 & 3,111 & $1,605-6,030$ \\
Perempuan & 28 & $36,8 \%$ & 49 & $64,5 \%$ & & & \\
\hline
\end{tabular}

Berdasarkan analisis multivariat pada tabel 3. menunjukkan bahwa variabel yang berhubungan dengan kejadian stunting yaitu tinggi badan ibu, pemberian ASI eksklusif, dan jenis kelamin. Sedangkan faktor yang bermakna secara statistik yaitu jenis kelamin $p$-value 0,002 (95\% CI 1,590-7,312), ASI eksklusif p-value 0,006 (95\% CI 1,366 -6,228)., dan tinggi badan ibu p-value 0,015 (95\% CI 1,495-40,012). Faktor dengan besar risiko paling besar terhadap kejadian stunting adalah tinggi badan ibu (95\% CI 1,495-40,012. Stunting berpeluang 7,735 kali pada balita yang memiliki ibu dengan tinggi badan kurang dari $145 \mathrm{~cm}$ daripada balita yang memiliki ibu dengan tinggi lebih dari $145 \mathrm{~cm}$.

Tabel 3. Hasil Analisis Multivariat Variabel Independen terhadap Kejadian Stunting di Wilayah Kerja Puskesmas Bontonyeleng

\begin{tabular}{|c|c|c|c|c|}
\hline Variabel & Koef. $\beta$ & $\mathbf{P}$ & $\mathbf{O R}$ & $95 \% \mathrm{CI}$ \\
\hline $\begin{array}{ll}\text { Tinggi badan ibu } \\
-\quad \text { Berisiko }(\leq 145 \mathrm{~cm}) \\
-\quad \text { Tidak Berisiko }(>145 \mathrm{~cm})\end{array}$ & 2,046 & 0,015 & 7,735 & $1,495-40,012$ \\
\hline $\begin{array}{l}\text { Tingkat Pendidikan } \\
-\quad \text { Rendah } \\
-\quad \text { Tinggi }\end{array}$ & 0,719 & 0,068 & 2,053 & $0,949-4,444$ \\
\hline $\begin{array}{l}\text { Status Ekonomi } \\
-\quad \text { Rendah } \\
-\quad \text { Tinggi }\end{array}$ & 0,696 & 0,089 & 2,005 & $0,900-4,467$ \\
\hline $\begin{array}{l}\text { ASI Eksklusif } \\
-\quad \text { Tidak Eksklusif } \\
-\quad \text { Eksklusif }\end{array}$ & 1,070 & 0,006 & 2,916 & $1,366-6,228$ \\
\hline $\begin{array}{l}\text { Berat Lahir } \\
-\quad \text { Kurang } \\
-\quad \text { Cukup }\end{array}$ & 1,023 & 0,085 & 2,780 & $0,867-8,915$ \\
\hline $\begin{array}{ll}\text { Jenis Kelamin } \\
-\quad \text { Laki-laki } \\
-\quad \text { Perempuan }\end{array}$ & 1,227 & 0,002 & 3,410 & $1,590-7,312$ \\
\hline
\end{tabular}

\section{PEMBAHASAN}

Hasil penelitian yang dilakukan pada balita usia 25-59 bulan di Posyandu Wilayah Puskesmas Bontonyeleng, hasil penelitian menyebutkan balita yang menglami stunting dan memiliki ibu dengan tinggi badan berisiko yaitu sebesar 18,4\%. Balita yang tidak mengalami stunting dan memiliki ibu dengan tinggi badan berisiko yaitu sebesar 2,6\%. Hasil uji statistik didapatkan p-value 0,004 berarti dapat disimpulkan bahwa ada hubungan antara tinggi badan 
ibu dengan kejadian stunting. Balita yang lahir dari ibu dengan tinggi badan kurang dari 145 cm berpeluang 8,355 kali (95\% CI 1,828-38,182) dibanding balita yang lahir dari ibu dengan tinggi lebih dari $145 \mathrm{~cm}$.

Hal ini didukung oleh penelitian yang dilakukan oleh Rahayu (2012), bahwa kejadian stunting pada balita usia 6-12 bulan dan usia 3-4 tahun secara signifikan berhubungan dengan tinggi badan ibu Rahayu, leni. 2012. Penelitian Candra (2011), dkk juga mengemukakan bahwa tinggi badan ibu memberikan pengaruh yang signifikan terhadap kejadian stunting pada balita, Candra A, 2011. Namun bertentangan dengan penelitian yang dilakukan oleh Anisa (2012) yang menyatakan bahwa tinggi badan ibu tidak berhubungan dengan kejadia stunting. Anisa, Paramitha. 2012.

Hasil penelitian ini menyatakan balita yang mengalami stunting dan memiliki ibu dengan tingkat pendidikan rendah sebesar $61,8 \%$. Balita yang tidak mengalami stunting dan memiliki ibu dengan tingkat pendidikan tinggi sebesar 36,8\%. Uji statistik didapatkan p-value 0,003 berarti dapat disimpulkan bahwa ada hubungan antara tingkat pendidikan ibu dengan kejadian stunting. Stunting berpeluang 2,778 kali $(95 \%$ CI 1,441-5,358) pada balita yang lahir dari ibu dengan tingkat pendidikan rendah dibanding balita yang lahir dari ibu dengan tingkat pendidikan tinggi.

Hasil penelitian tersebut juga didukung oleh penelitian yang dilakukan oleh Haile (2013) yang juga menyatakan bahwa balita yang terlahir dari orang tua yang berpendidikan berpotensi lebih rendah menderita stunting dibandingkan balita yang memiliki orang tua yang tidak berpendidikan. Hal ini dikarenakan orang tua yang memiliki pendidikan tinggi lebih mudah untuk menerima edukasi kesehatan selama kehamilan, misalnya dalam pentingnya memenuhi kebutuhan nutrisi saat hamil dan pemberian ASI eksklusif selama 6 bulan. Haile, 2016. Hasil penelitian ini menyatakan balita yang mengalami stunting dan memiliki status ekonomi rendah yaitu sebesar 76,3\%, sedangkan balita yang tidak mengalami stunting dan memiliki status ekonomi rendah yaitu sebesar 55,3\%.. Hasil uji statistik didapatkan p-value 0,010 berarti dapat disimpulkan bahwa ada hubungan antara status ekonomi dengan Kejadian Stunting. Stunting berpeluang 2,608 kali (95\% CI 1,301-5,231) pada balita yang memiliki status ekonomi rendah dibanding balita dengan status ekonomi tinggi.

Hasil penelitian tersebut juga didukung oleh Azwar (2000) yang menyatakan bahwa pendapatan keluarga yang memadai akan menunjang perilaku anggota keluarga untuk mendapatkan pelayanan kesehatan keluarga yang lebih memadai. Dalam hal ini termasuk pelayanan kesehatan yang didapatkan selama kehamilan. Hal ini disebabkan apabila 
seseorang mengalami kurang gizi maka secara langsung akan menyebabkan hilangnya produktifitas kerja karena kekurangan fisik, menurunnya fungsi kognitif yang akan mempengaruhi tingkat pendidikan dan tingkat ekonomi keluarga. Notoatmodjo, 2003.

Banyaknya manfaat ASI bagi pertumbuhan dan perkembangan inilah yang mendukung hasil penelitian ini. Hasil penelitian ini menunjukan balita yang mengalami stunting dan tidak ASI eksklusif sebesar $67,1 \%$, sedangkan balita yang mengalami stunting dan tidak mendapat ASI eksklusif yaitu sebesar 38,2\%. Hasil uji statistik didapatkan p-value 0,001 berarti dapat disimpulkan bahwa ada hubungan Kementrian Kesehatan RI. 2012. antara pemberian ASI eksklusifdengan Kejadian Stunting. Stunting berpeluang 3,306 kali (95\% CI 1,699-6,433) pada balita yang tidakmendapatkan ASI eksklusif dibanding balita yang mendapat ASI eksklusif.

Hal ini bertentangan dengan penelitian yang dilakukan Anisa (2012) yang menyatakan bahwa pemberian ASI Eksklusif tidak berhubungan secara signifikan terhadap kejadian stunting. Namun sejalan dengan penelitian yang dilakukan oleh Al-Rahmad (2013) yang menyatakan bahwa kejadian stunting disebabkan oleh pemberian ASI yang tidak eksklusif. ${ }^{34}$ Hal serupa dinyatakan pula oleh Arifin (2012) dengan hasil penelitian yang menyatakan bahwa Kejadian Stunting dipengaruhi oleh berat badan saat lahir, pengetahuan gizi ibu balita, pendapatan keluarga, jarak antar kelahiran, pemberian ASI yang tidak ekskusif. Namun faktor yang paling dominan adalah pemberian ASI.

Hasil penelitian ini menunjukan bahwa balita yang mengalami stunting dan berjenis kelamin laki-laki yaitu sebesar $63,2 \%$. Balita yang tidak mengalami stunting dan berjenis kelamin laki-laki yaitu sebesar 35,5\%. Hasil uji statistik didapatkan p-value 0,001 berarti dapat disimpulkan bahwa ada hubungan antara jenis kelamin dengan kejadian stunting. Stunting berpeluang 3,111 kali (95\% CI 1,605-6,030) pada balita yang berjenis kelamin lakilaki berpeluang dibanding balita yang berjenis kelamin perempuan.

Hal ini didukung oleh sudi kohort yang dilakukan Medin (2010) yang menunjukan bayi dengan jenis kelamin lai-laki memiliki risiko dua kali lipat menjadi stunting dibandingkan bayi perempuan. Medhin, Gima et al. 2010. Balita laki-laki lebih berisiko stunting dibandingkan balita perempuan.

Dari ketiga faktor yang memiliki hubungan yang relevan terhadap kejadian stunting, tinggi badan ibu merupakan faktor dengan besar risiko paling besar terhadap kejadian stunting. Hal ini dapat dilihat dari hasil analisis multivariat yaitu p-value 0,015 (95\% CI 1,495-40,012). Hasil penelitian menunjukan anak yang memiliki ibu dengan tinggi badan 
kurang dari $145 \mathrm{~cm}$ berpeluang 7,735 kali mengalami stunting dibandingkan anak yang memiliki ibu dengan tinggi badan lebih dari $145 \mathrm{~cm}$.

Hal ini didukung oleh penelitian yang dilakukan oleh Rahayu (2012), bahwa kejadian stuning pada balita usia 6-12 bulan dan usia 3-4 tahun secara signifikan berhubungan dengan tinggi badan ibu. Rahayu, 2012.

Penelitian Candra (2011), dkk juga mengemukakan bahwa tinggi badan ibu memberikan pengaruh yang signifikan terhadap kejadian stunting pada balita, Candra A, 2011. Namun bertentangan dengan penelitian yang dilakukan oleh Anisa (2012) yang menyatakan bahwa tinggi badan ibu tidak berhubungan dengan kejadia stunting.

\section{KESIMPULAN DAN SARAN}

Berdasarkan hasil dari analisis data dan pembahasan dalam penelitian ini, maka dapat ditarik kesimpulan yaitu Tinggi badan ibu mempunyai hubungan bermakna dengan Kejadian Stunting, p-value 0,015 (95\% CI 1,495-40,012). Balita yang memiliki ibu dengan tinggi badan berisiko berpeluang 7,735 kali mengalami stunting dibandingkan balita yang memiliki ibu dengan tinggi badan tidak berisiko atau lebih dari $145 \mathrm{~cm}$. Pemberian ASI eksklusif mempunyai hubungan bermakna dengan Kejadian Stunting, p-value 0,006 (95\% CI 1,366 - 6,228). Balita yang tidak diberi ASI eksklusif berisiko berpeluang 2,916 kali mengalami stunting dibandingkan balita yang diberi ASI eksklusif.

Jenis kelamin mempunyai hubungan bermakna dengan Kejadian Stunting, p-value 0,002 (95\% CI 1,590-7,312). Balita dengan jenis kelamin laki-laki berisiko berpeluang 3,410 kali mengalami stunting dibandingkan balita berjenis kelamin perempuan.

Faktor yang paling berhubungan dengan kejadian stunting yaitu tinggi badan ibu OR 7,735. Hasil penelitian ini dapat dijadikan sebagai masukan bagi bidan Puskesmas Bontonyeleng untuk menggalakan pemberian ASI Eksklusif, sehingga dapat menekan kejadian stunting, Apabila memungkinkan dilakukan penelitian lebih lanjut, hendaknya menggunakan kohort prospektif sehingga dapat diikuti sejak kelahiran balita mengenai faktorfaktor apa saja yang berhubungan dengan kejadian stunting pada balita.

\section{DAFTAR PUSTAKA}

Word Health Organization. 2013. Childhoold Stunting: Challenges and Opportunities. Switzerland: Department of Nutrition for Health and Development. www.who.int. Diakses 20 April 2016

UNICEF. 2016. A Fair Chance For Every Child. New York. USA www.unicef.org/publications. Diakses 20 April 2017

UNICEF. 2009. Tracking Progress on Child and Maternal Nutrition a Survival and Development Priority. New York. USA www.unicef.org/publications. Diakses 20 April 2017 
UNICEF. 2014. The State of the World ${ }^{\text {ee }}$ Children 2014 in Numbers. Everychild Counts: Revealing Disparities, Advancing Children"s Rights. New York. USA www.unicef.org/publications. Diakses 20 April 2017

Kementrian Kesehatan RI. 2013. Riset Kesehatan Dasar Tahun 2013. Jakarta: Kemenkes RI. Diunduh tanggal 10 April 2017 dari www.depkes.go.id

Kementerian Kesehatan RI. 2015. Infodatin Pusat Data dan Informasi Kementerian Kesehatan Republik Indonesia. Jakarta: Kemenkes RI. Diunduh tanggal 10 April 2017 dari http://www.pusdatin.kemkes.go.id

Dinas Kesehatan SUL-SEL. 2016. Profil Kesehatan SUL-SEL Tahun 2016. Yogyakarta: Dinkes SUL-SEL

Kementrian Kesehatan RI. 2016. Pusat Data dan Informasi 2015. Jakarta: Kemenkes RI. Diunduh tanggal 12 April 2017 dari http://www.depkes.go.id

Dinas Kesehatan Kabupaten Bulukumba. 2016. Profil Kesehatan Kabupaten Bulukumba Tahun 2016. Yogyakarta: Dinkes Kabupaten Bulukumba

UNICEF. 2007. Women and Children The Double Dividend of Gender Equality

New York. USA www.unicef.org/publications. Diakses 20 April 2017

Tiwari, Rina, Ausman Lynne M, Agho Kingsley Emwinyore. 2014.Determinants of stunting and severe stunting among under-fives: evidence from the 2011 Nepal Demographic and Health Survey.Nepal: BMC Pediatrics

Akombi, Blessing Jaka. Agho Kingsley E, Hall John J, Merom Dafna, Astel- Burt Thomas, and Renzaho Andre M.N. 2017. Stunting and severe stunting among children under-5 years in Nigeria: A multilevel analysis. Nigeria: BMC Pediatrics

Haile, Demwoz, Azage Muluken, Mola Tegegn, and Rainey Rochelle. 2016. Exploring spatial variations and factors associated with childhood stunting in Ethiopia: spatial and multilevel analysis. Eithopia: BMC Pediatrics

Kementrian Kesehatan RI. 2010. Riset Kesehatan Dasar Tahun 2010. Jakarta: Kemenkes RI. Diunduh tanggal 10 April 2017 dari www.depkes.go.id

Ali, Zakari, Saaka Mahama, Adams Abdul-Ganiyu, Kamwininaang Stephen K, Abizari Abdul-Razak. 2017. The effect of maternal and child factors on stunting, wasting and underweight among preschool children in Northern Ghana. Ghana: BMC Nutrition

Aryastami, Ni Ketut, Shankar Anuraj, Kusumawardani Nunik, Besral Besral, Jahari Abas Basuni, Achadi Endang. 2017. Low birth weight was the most dominant predictor associated with stunting among children aged 12-23 months in Indonesia. Indonesia: BMC Nutrition

World Health Organization. 2012. World Health Statistics 2012. Switzerland: Department of Nutrition for Health and Development. www.who.int. Diakses 20 April 2016

Senbanjo, I., et al. 2011. Prevalence of and Risk factors for Stunting among School Children and Adolescents in Abeokuta, Southwest Nigeria. Journal of Health Population and Nutrition. 29(4):364-370.

Kementrian Kesehatan RI. 2012. Keputusan Menteri Kesehatan Republik Indonesia Nomor: 1995/MENKES/SK/XII/2010. Jakarta: Kemenkes RI. Diunduh tanggal 01 Juni 2017 dari http://www.gizi.depkes.go.id

Gibson, R. S. 2005. Principles of Nutritional Assessment. Second Edition. Oxford University Press Inc, New York

Supariasa. 2001. Penilaian Status Gizi. Buku Kedokteran EGC.Jakarta.Kementrian Kesehatan RI. 2007.

Riset Kesehatan Dasar Tahun 2007. Jakarta: Kemenkes RI. Diunduh tanggal 10 April 2017 dari www.depkes.go.id 
Kementrian Kesehatan RI. 2010. Riset Kesehatan Dasar Tahun 2010. Jakarta: Kemenkes RI. Diunduh tanggal 10 April 2017 dari www.depkes.go.id

UNICEF. 1998. The State of The World's Children. Oxford University press.

Anisa, Paramitha. 2012. Faktor-Faktor Yang Berhubungan Dengan Kejadian Stunting Pada Balita Usia 25-60 Bulan Di Kelurahan Kalibiru Depok Tahun 2012. Jakarta: Universitas Indonesia.

Direktorat Bina Kesehatan Ibu . 2012. Direktorat Bina Kesehatan Ibu Akan Lakukan Assessment Kualitas Pelayanan Kesehatan Ibu di 20 Kabupaten/Kota. Diunduh 20 April 2017, dari Kesehatan Ibu:http://www.depkes.go.id

Sartono. 2013. Hubungan Kurang Energi Kronis Ibu Hamil Dengan Kejadian Stunting Pada Anak Usia 6 - 24 Bulan Di Kota Yogyakarta. Tesis. Universitas Gajah Mada. Yogyakarta.

Milman, A., Frongillo, E. A., Onis, M., and Hwang J-Y. 2005. Differential Improvement among Countries in Child Stunting is Associated with Long-Term Development and Specific Interventions. The Journal of Nutrition.

Ramli, et al. 2009. Prevalence and Risk Factor for Stunting and Severe Stunting Among Under Fives in North Maluku Province of Indonesia. BMC Pediatrics. Press, Inc. Florida. Page. 147-198.

Medhin, Gima et al. 2010. Prevalence and Predictors Of Undernutrition Among Infants Age Six and Twelve Months In Butajira, Ethiopia: The P-MaMiE Birth Cohort. Mdhin et al. BMC Public Health, 10:27. Dapat diakses di www.biomedcentral.com.

Lesiapeto, et al. 2010. Risk Factors of Poor Anthropometric Status In Children Under Five Years of Age Living In Rural Districts of The Eastern Cape And Kwazulu-Natal Provinces, South Africa. S Afr J Clin Nutr, 23(4): 202-207. Dapat diakses di www.sajcn.co.za.

Taguri, AE et al. 2008. Risk Factor For Stunting Among Under Five In Libya. Public health nutrition, 12 (8), 1141-1149. Dapat diakses di www.ncbi.nlm.nih.gov.

Semba, et al. 2008. Effect Parental Formal Education On Risk Of Child Stunting In Indonesia And Bangladesh : A Cross Sectional Study. 371 : 322 - 328. www.thelancet.com.

AL - Rahmad Ah, Miko A, Hadi A. 2013. Kajian Stunting Pada Anak Balita Ditinjau Dari Pemberian ASI Eksklusif, MP-ASI, Status Imunisasi, Dan Karakteristik Keluarga Di Kota Banda Aceh. Jurnal Kesehatan Ilmiah Nasawakes. 6(2) : 169 - 184. 
Arifin, D.Z., Irdasari, S.Y., Sukandar,H. 2012. Analisis sebaran dan faktor resiko stunting pada balita di Kabupaten Purwakarta. Epidemiologi Komunitas FKUP Bandung.

Rahayu, leni. 2012. Hubungan Pendidikan Orang Tua Dengan Perubahan Status Stunting Dari Usia 6-12 Bulan Ke Usia 3-4 Tahun. http://lemlit.uhamka.ac.id/files/makalah7leni.pdf. Diakses 6 Januari 2017.

Jesmin Aklima et al, 2011, Prevalence and Determinants of Chronic Malnutritionamong Preschool Children: A Cross-sectional Study in Dhaka City,Bangladesh. Journal of Health Population and Nutrition, vol 29, pp 494- 499.

Candra A., Puruhita N., Susanto J.C., 2011. Risk Factors of Stunting among 1-2 Years Old Children in Semarang City. M Med Indones, 45(3): 206-12.

Manurung, Joni J, Adler dan Ferdinand. 2009, Ekonomi Keuangan dan Kebijakan Moneter, Jakarta: Penerbit Salemba Empat.

BAPPENAS. 2011. Rencana Aksi Nasional Pangan dan Gizi 2011-2015. http://www.4shared.com/get/I45gBOZ/Rencana_Aksi_Nasional_Pangan.Diakss 8 Mei 2017.

Badan Pusat Statistik Jakarta Pusat. 2011. Pedoman Pendataan Survei Sosial Ekonomi Nasional Tahun 2011. Jakarta Pusat : Badan Pusat Statistik.

Notoatmodjo, Soekidjo. 2003. Pendidikan Dan Perilaku Kesehatan. Rineka Cipta. Jakarta.

Kementrian Kesehatan RI. 2010. Keputusan Menteri Kesehatan Republik Indonesia NOMOR: 1995/MENKES/SK/XII/2010 Tentang Standar Antropometri Penilaian Status Gizi Anak. Jakarta: Kemenkes RI. Diunduh tanggal 12 April 2017 dari http://www.depkes.go.id

Sastroasmoro, S dan Ismail, S. 2014. Dasar-Dasar Metodologi Penelitian Klinis. Ed. 5. Jakarta: Sagung Seto

Sugiyono. 2010. Metode Penelitian Pendidikan: Pendekatan Kuantitatif, Kualitatif, dan $R \& D$. Bandung: Alfabeta

Notoatmodjo, S. 2012. Metodologi Penelitian Kesehatan. Jakarta: Rieneka Cipta 